1975

\title{
The Brain Drain: A Tax Analysis of the Bhagwati Proposal
}

Richard Pomp

University of Connecticut School of Law

Follow this and additional works at: https://opencommons.uconn.edu/law_papers

Part of the Tax Law Commons

\section{Recommended Citation}

Pomp, Richard, "The Brain Drain: A Tax Analysis of the Bhagwati Proposal" (1975). Faculty Articles and Papers. 549.

https://opencommons.uconn.edu/law_papers/549 


\title{
The Brain Drain: A Tax Analysis of the Bhagwati Proposal
}

\author{
OLIVER OLDMAN* \\ International Tax Program, Harvard Law School \\ and \\ RICHARD POMP \\ International Tax Program, Harvard Law School \\ and \\ Boston College Law School
}

\begin{abstract}
Summary. - To alleviate the problems caused by the brain drain, Professor Bhagwati proposes that professional, technical, and kindred persons who emigrate from less developed countries be subjected to a special tax on the income they earn in developed countries. This paper highlights the political and legal issues raised by his proposal and examines three approaches to implementation: a tax levied by the less developed country, a tax levied by the developed country, and a tax levied by the United Nations. Specific aspects of the proposal which require further study and refinement, such as administrative feasibility, are outlined.
\end{abstract}

\section{INTRODUCTION}

\section{A. Appraisal of the problem}

Skilled manpower is a key ingredient of economic development. For a number of years, however, many less developed countries (LDCs) have experienced what is popularly known as a 'brain drain'-the emigration of their most talented individuals to the developed countries (DCs). The emigration is due in part to the higher salaries prevailing in the DCs. An LDC that is unwilling or unable to offer comparable salaries will often lose essential professional, leadership, and entrepreneurial abilities. Other problems occur even if the LDC is able to compete with the salaries offered in the international market. Although more professionals are induced to stay at home, their relatively high salaries create harsh income inequalities and social strain within the LDC.

In response to these problems, Professor Jagdish Bhagwati of MIT has suggested taxing the earnings 1 of professionals, technicians, and kindred persons (PTKs) who emigrate to DCs. The tax would have a number of objectives.
First, by effectively reducing the existing salaries for PTKs in the international market, the tax would allow the LDC to pay its resident PTK a wage that was more consistent with the social objectives of the country. The trend toward increased income inequality might then be partially averted. Second, the revenue from the tax would help compensate the LDC for the burdens imposed by emigration. Third, the tax would enable the LDC to share in the improved incomes of its emigrants. Finally, by reducing

\footnotetext{
* The authors wish to express their sincere appreciation to Michael J. McIntyre, Director of Training, International Tax Program, Harvard Law School, for his critical insights in reviewing an earlier draft of this paper.

1. Although our analysis is concerned with the taxation of earned income, our conclusions are generally applicable to the taxation of unearned income.
} 
the economic returns to emigration, the $\operatorname{tax}$ might discourage the loss of manpower. ${ }^{2}$

In order to accomplish these objectives, Bhagwati proposes that the host DC levy a special tax on the earnings of immigrant PTKs. The DC would then remit the proceeds of the tax to the LDC of origin. Alternatively, Bhagwati suggests that the tax on PTK earnings be levied by the United Nations, with the proceeds either remitted to the $\mathrm{LDC}$ of origin or earmarked for general developmental aid to the LDCs.

Imposing a tax on PTKs to alleviate the losses caused by the brain drain raises fundamental moral and political questions about the individual's relationship to society and his rights of self-realization and fulfilment. ${ }^{3}$ The crux of the problem lies in balancing the legitimate interests of society against the interests of the individual. Given the disparate economic, cultural, and perhaps political perspectives of the DCs and the LDCs, opinions will differ on how the balance should be struck.

The DCs will tend to strike the balance on the side of the PTK and will react negatively if the tax has a serious impact on emigration. Moreover, even if the impact is negligible, some will find the tax offensive if the PTKs' primary motive for leaving the LDC were to escape political or religious oppression. The fairness and justice in placing financial responsibility for aiding the LDCs on the shoulders of the PTKs will also be questioned, especially if emigration was the result of a lack of professional opportunities in the LDC. Indeed, comparing the immigrant PTK with citizens of the DC, some may argue that instead of paying a tax, the PTK deserves to be compensated for the hardships and cultural deprivation he endured while in the LDC.

The LDCs, by comparison, will strike the balance on the side of society. Mitigating the harsh economic conditions in the LDC will take priority over the desires of individuals. The PTK will thus be seen as having an obligation to contribute to his counlry's development. If the salary and the standard of living enjoyed by the PTK in the DC are compared with conditions in the LDC, the emigrant PTK will appear to have the capacity to bear an additional tax burden. Furthermore, the LDCs will urge that the DCs have not only an obligation but also the capability necessary to administer any tax designed to impose that burden.

Since no simple means of resolving these issues exists, the Bhagwati proposal should be structured so that it minimizes the differences in perspective between the LDCs and the DCs.
At the least, the rate of tax should be low enough so that it does not materially affect the individual's decision to emigrate. Subject to this caveat, two alternatives seem realistic. In view of the sensitive issues of human rights involved -rights that may be guaranteed under international law ${ }^{4}$-one alternative would be for the United Nations to design and administer the tax. Reaching a consensus among the members of the United Nations with respect to the implementation of the tax might be difficult, however.

A second alternative would be to conform the Bhagwati proposal as closely as possible to existing patterns of taxation. Under this approach, the LDC would tax the foreign earnings of all its non-resident citizens, rather than singling out PTKs for special treatment. As long as the PTK remained a citizen of the LDC, he would automatically fall within the LDC's jurisdiction. In taxing the earnings of all of its non-resident citizens, the LDC would be adopting an approach already used by the United States, Mexico, and the Philippines.

An LDC tax on the foreign earnings of all non-resident citizens may not be practicable for very many LDCs because of enforcement problems. Nonetheless, we have chosen this alternative as the focus of our paper because dis-

2. The restrictions that each DC imposes on entry may already reduce immigration to a level below what would exist in the absence of all controls. Thus, the tax could affect only the size of the waiting list (i.e., the excess demand) for entry into the DC, and not the actual level of immigration. The effect of the tax on immigration levels must be distinguished, however, from the effect of the tax on an individual's decision to emigrate. A reduction in the size of the waiting lists would indicate that the tax has deterred some individuals from attempting to emigrate.

3. To be sure, the immigration restrictions of the DCs may raise similar philosophical problems. Emigration and immigration restrictions do differ, however, in at least one important way. Since immigration restrictions vary from country to country, an individual may be prevented from entering the DC of his preference, but he will no doubt be able to obtain entry to some other DC. That option would obviously be precluded if the tax were an obstacle to leaving the LDC at all.

4. For a discussion of the possible conflicts between the Bhagwati proposal and rights guaranteed under international law, see Frank Newman, 'The brain drain tax and international human rights law', paper presented at the Bellagio Conference, 15-19 February 1975 , and to appear in the volume edited by Bhagwati and Partington, Taxing the Brain Drain: A Proposal. 
cussion of an LDC tax will highlight many of the legal and administrative issues underlying the Bhagwati proposal. An understanding of these issues is necessary to evaluate competing proposals and to provide a foundation for further discussion.

Many of the legal and administrative issues raised by the Bhagwati proposal are complex and involve matters of dispute among tax specialists. Because of the varied backgrounds of the conferees, we will not attempt to present the debates in detail, but rather only a broad outline of the major issues. We will concentrate on the refinements needed to make the Bhagwati proposal feasible and acceptable in view of general notions of international tax equity.

Given the theme of this conference, we will also explore briefly other tax measures for transferring resources to the LDCs. For example, PTKs could be encouraged, rather than compelled, to make contributions to the LDCs through the use of tax incentives. Another approach would be for the United Nations to assess the host DCs, rather than the PTKs, and remit the proceeds to the LDCs. Though these other approaches might not accomplish all of Bhagwati's goals, one or a combination of them could prove ultimately to be the most politically acceptable response to the brain drain.

\section{B. International income taxx rules}

Many of the legal issues raised by a tax on emigrant PTKs are jurisdictional in nature. That is, they involve the rules governing the extent of a country's taxing powers. Countries have generally exercised self-restraint in asserting their tax jurisdiction. The practicalities of enforcement and the fear that a broad assertion of jurisdiction might offend foreign governments have kept countries from exercising their taxing powers in ways that would create conflicts among countries. Accordingly, rules of tax jurisdiction exist in the sense that certain patterns of taxation are acceptable as a matter of international custom. No international law exists, however, defining the outer limits of a country's tax jurisdiction. 5

In order effectively to assert jurisdiction to tax income, a country must rely on some minimum connection or nexus between itself and the taxpayer or between itself and the income being taxed. 6 In terms of the nature of this nexus, tax systems can be classified into two major groups: schedular systems and global or unitary systems. Under a pure schedular system, the jurisdictional connection is the source of the income. 7 Only income from domestic sources is taxed $; 8$ no jurisdiction is asserted over income from foreign sources. Since all countries tax income from domestic sources, any country that uses a schedular system-that taxes only domestic incomeexercises the most limited form of tax jurisdiction.

In a global system, an additional jurisdictional connection is the personal status of the taxpayer. Jurisdiction is thus based on two independent factors: the source of the income and the status of the taxpayer. Under most global systems, residence is the connection relied on in asserting tax jurisdiction over individuals. In a few countries, including the United States, Mexico, and the Philippines, citizenship alone is a sufficient connection. ${ }^{9}$ These countries, however, also tax non-citizens who are residents. That is, either statuscitizenship or residence-is sufficient for the assertion of tax jurisdiction, though the vast majority of taxpayers are both citizens and residents. Countries using a global system tax all income of their citizens and residents, regardless of its geographical source. In other words, income from foreign sources is taxed along with domestic income.

The difference between taxing on a residence basis and taxing on a citizenship basis can be illustrated by considering taxpayer $A$, who is a citizen of country $X$. Assume $A$ moves abroad and is no longer considered by $X$ to be a resident. If $X$ taxes on the basis of citizenship,

5. Compare Matin Norr, 'Jurisdiction to tax and international income', Tax Law Review, Vol. 17 (1962) p. 431, with Stanford Ross, 'United States taxation of aliens and foreign corporations: the Foreign Investors Tax Act of 1966 and related developments', Tax Law Review, Vol. 22 (1967) p. 363 .

6. Norr, op. cit., p. 432.

7. ibid., p. 434.

8. Different types of domestic income may be taxed in different ways. See, generally, 'Schedular and global income taxes', in Richard M. Bird and Oliver Oldman (eds.), Readings on Taxation in Developing Countries (Baltimore: The Johns Hopkins Press, rev. ed. 1967). p. 132. The personal status of the taxpayer may be relevant in determining the rate applied to the income.

9. See, generally, Douglas Sherbaniuk, Henry Hutcheon, and Pearley. Brissenden, 'Liability for taxresidence, domicile or citizenship?', in Canadian Tax Foundation, Report of Proceedings of the Seventeenth Annual Tax Conference (Toronto, 1964) p. 315. 
$A$ 's change of residence will be irrelevant and $X$ will $\operatorname{tax} A$ not only on income earned within $X$, but also on any income earned abroad. By comparison, if $X$ taxes only on the basis of residence, it will no longer assert jurisdiction over $A$ on the basis of his personal status. Thus $X$ will not $\operatorname{tax} A$ on income earned abroad. $X$ will $\operatorname{tax} A$, however, on income received from sources within $X$. In this case, the source of the income is a sufficient connection with the country to warrant the assertion of its tax jurisdiction.

Most income tax systems are hybrids, employing some combination of the global and schedular concepts. For example, a global-type system might tax foreign income differently from domestic income. To this extent, foreign income would receive schedular treatment. A global system is probably used more often by the DCs, a schedular system more often by the LDCs. The trend, however, in the LDCs is toward use of the global approach.

\section{APPROACHES TO THE TAXATION OF EMIGRANT PTKs}

This section analyses three basic approaches to the taxation of emigrant PTKs. Part A considers the problems raised in the extension of an LDC's tax jurisdiction to reach the earnings of emigrant PTKs. In Part B, Bhagwati's proposal of a DC tax is treated by examining the case of the United States. The use of a deduction for charitable contributions is also discussed as an alternative measure. Part $C$ explores two approaches the United Nations can adopt: a tax on PTKs and an assessment on host DCs based on the benefits they have received from the immigration of PTKs.

\section{A. LDC taxation of emigrant PTKs}

1. Jurisdictional issues. In order to tax the income earned abroad by an emigrant PTK, the LDC must assert jurisdiction on the basis of the personal status of the PTK. If the LDC relies on residence as its jurisdictional nexus, as do most global-type countries, the jurisdictional issue involved in taxing the PTK is the definition of 'resident'.

The definition of 'resident' varies markedly from country to country. Some countries follow specific rules that define residence in terms of the period of time a person has been within or without the country. Other countries decide the question on an almost ad hoc basis, with little guidance from statutes. Often, a combination of the two approaches is adopted. 10

Whatever the approach, the basic question is: at what point does a PTK working abroad cease being a resident of the LDC? The factors that most countries would consider are the intent of the PTK with respect to his being abroad, the length of his stay abroad, and the nature of his contacts with both countries. For example, a PTK who was sent abroad by his employer for short-term training would clearly remain a resident of the LDC. In contrast, the PTKs whom the Bhagwati proposal is intended to reach-those who have emigrated abroad-are the least likely to fall within the usual concepts of residence.

In order to assert jurisdiction over emigrant PTKs, the LDC has two options. The first is to define residence in terms of a person's prior contacts with the LDC, even though all these contacts may have been severed long ago. This definition of residence would be broader than that so far adopted by any country. As explained in Section I(B) such a broad assertion of jurisdiction could not be said to violate international law, but because it would be out of the mainstream of international custom and practice, two serious problems could arise. First, the DC might refuse to recognize the LDC's definition, especially since it would conflict with the DC's claim of residence over the PTK. A DC that viewed the LDC's assertion of jurisdiction as illegitimate would obviously not co-operate with the LDC in policing the tax on PTKs. Second, the LDC's claim of residence would make little sense to a PTK who had cut all his ties with the LDC. He might therefore ignore the claim and refuse to comply voluntarily with the tax.

The second option is for the LDC lo follow the pattern established by the United States, Mexico, and the Philippines, and assert tax

10. For illustrations of the approaches some countries use, see Harvard Law School, International Tax Program, World Tax Series (hereinafter WTS): Taxation in Australia (Boston: Little, Brown \& Co., 1958) 5/1; WTS, Taxation in the Federal Republic of Germany (Chicago: Commerce Clearing House, Inc., 1963) 2/2; WTS, Taxation in Sweden (Boston: Little, Brown \& Co., 1959) $5 / 1$. The definition of resident may be different for citizens or nationals than for aliens. See WTS, Taxation in Colombia (Chicago: Commerce Clearing House, Inc., 1964) 11/1.2. 
jurisdiction on the basis of citizenship. ${ }^{1} 1$ Since these three countries apply citizenship jurisdiction uniformly to all citizens, the LDC could not limit citizenship jurisdiction to PTKs without encountering serious problems. As discussed in Section $I(A)$ the singling out of emigrant PTKs for special treatment would raise delicate political and moral problems and may violate certain human rights guaranteed under international law, 12 These problems, like those arising from an unorthodox definition of residence, 13 would be obstacles to obtaining the administrative assistance of the DCs and to obtaining the voluntary compliance of the PTKs.

Other reasons exist for the $L D C$ not to limit its citizenship jurisdiction to PTKs. By bringing all non-resident citizens into its tax net, an LDC could broaden its tax base. ${ }^{4}$ With a larger tax base, the LDC could lower its tax rate on foreign income and still raise as much revenue as it would by applying a higher rate to just the earnings of PTKs. Keeping the tax rate low has two major advantages. First, the emigrant PTK is not likely to engage in tax avoidance or evasion if the amount of tax at stake is not large. Second, the PTK's decision to emigrate is unlikely to be affected by a low rate; thus conflict with basic individual rights can be avoided.

If all non-resident citizens are brought into the $\operatorname{tax}$ net, 15 the LDC need not define who is a PTK for tax purposes. Any attempt to define a PTK would involve drawing fine distinctions, and considerable strain would be placed on the definition by manoeuvres to circumvent it. Any weakness in the definition would operate to the advantage of the taxpayer.

2. Renunciation of citizenship by the PTK. The LDC's assertion of jurisdiction on the basis of citizenship might induce a PTK to renounce his citizenship in order to avoid LDC taxation. Though one result would be a revenue loss to the LDC, another, more important, consequence would be a lowering of the probability that the PTK would eventually return to the LDC. Imposing an income tax on non-resident citizens might therefore not be in the LDC's best interests to the extent that it resulted in wholesale renunciations of citizenship.

Could the LDC ignore a PTK's renunciation of citizenship, at least for the purpose of asserting tax jurisdiction? Again, international law offers little guidance since no country has attempted such a broad assertion of tax jurisdiction. 16 It may, however, be useful to distinguish two situations. A PTK who renounces his LDC citizenship can either acquire a new citizenship or else become stateless. The LDC's assertion of tax jurisdiction over the PIK once he has acquired citizenship in the DC would raise the same problems as an unorthodox definition of residence. In contrast, an LDC policy that discouraged persons from becoming stateless in order to avoid taxation would seem reasonable. 17 Thus one approach the LDC could adopt would be to recognize the

11. In some countries, the taxation of the foreign earnings of a non-resident citizen may conflict with constitutional doctrines proscribing legislation having an extraterritorial effect. For example, some Canadian constitutional-law scholars felt that, prior to 1931 , Canada was precluded from enacting legislation having an extraterritorial effect. In 1931, the Canadian Parliament ${ }_{2}$ passed the Statute of ${ }^{\circ}$ Westminster, which expressly authorized such legislation. The Statute of Westminster clearly established the power to tax nonresident citizens on their foreign income, though Canada has never chosen to exercise this power. Sherbaniuk, Hutcheon, and Brissenden, op. cit., p. 316.

12. The LDC's domestic law may also prevent the singling out of PTKs for special tax treatment.

13. An assertion of citizenship jurisdiction by the LDC might also be viewed as creating a conflict between the two countries. The short answer is that countries accept certain conflicts as being legitimate and inevitable. The conflict between citizenship jurisdiction and residence jurisdiction is, by custom and practice, considered acceptable. The conflict created by a deviant definition of resident would, however, be considered illegitimate.

14. The extent to which the tax base could be broadened depends on how narrow a definition of PTK an LDC contemplated.

15. In some LDCs, e.g., Britain's former colonies in Africa, the brain drain may consist of PTKs who are not citizens of the LDC. The assertion of citizenship jurisdiction would obviously not reach this group.

16. The United States has a provision designed to discourage citizens from giving up their citizenship and moving abroad in order to avoid US tax. Internal Revenue Code of 1954, $\$ 877$. The special tax imposed on expatriates extends only to their US investment income and income effectively connected with the conduct of a trade or business within the United States. No attempt is made to tax their foreign earnings that have no connection with the United States.

17. Statelessness is frowned upon in international law. See Paul Weis, 'The United Nations Convention on the Reduction of Statelessness, 1961', International and Comparative Law Quarterly, Vol. 11 (1962) p. 1073. 
PTK's renunciation of citizenship only if he obtained a new citizenship. ${ }^{18}$ In the case of a PTK who had emigrated to the United States, the LDC could levy its tax for at least five years, which is the length of time an immigrant must normally wait before applying for US citizenship. 19

If the LDC asserts tax jurisdiction over the PTK during his first five years in the United States, the PTK would have nothing to gain from renouncing his LDC citizenship. From the LDC's point of view, however, limiting taxation to a five-year period may reduce potential revenues. The PTK's early years in a DC might not be productive in terms of income, especially if he spends part of the time in school. Furthermore, the PTK may be able to reduce his income during this period by working under a deferred compensation agreement.

Devising rules to minimize tax avoidance through renunciation of citizenship is difficult, and no one solution appears to be completely satisfactory. The problem of wholesale renunciations may, however, be larger in theory than in fact. An LDC tax that imposes only a modest burden on the PTK is not likely to result in renunciation. Renunciation would also be unattractive to a PTK whose close family members remained in the LDC with no thought of emigrating or to a PTK who was uncertain about his future plans. Moreover, cultural and social patterns are likely to influence a PTK's decision; the strength of his ties to the LDC may outweigh the tax savings from renunciation.

3. Relief from double taxation. International double taxation can result when a taxpayer or his income has jurisdictional connections with more than one country. Since a DC will tax a PTK on income earned within the DC, double taxation will occur if the LDC also taxes the PTK.

Suppose a PTK has taxable income of $\$ 20,000$ derived entirely from employment within the United States. Assume that the US tax would be levied at an effective rate of 25 per cent, resulting in a US tax liability of $\$ 5,000$. If the LDC levies its regular income tax on the same base, $20 \$ 20,000$, at an effective rate of 45 per cent, the LDC tax liability would be $\$ 9,000$. The lotal tax burden on the PTK's earnings would be $\$ 14,000(\$ 5,000+\$ 9,000)$, for an over-all effective rate of 70 per cent.

As the example illustrates, the burden of double taxation can be quite onerous. Most countries that tax foreign income therefore use some type of credit mechanism to provide relief. 21 In its simplest form, such a mechanism would require the taxpayer to compute his tax liability and then take as a credit against that liability the amount of any foreign tax paid on the income. 22 The PTK in the example would take a credit for the US tax of $\$ 5,000$, thereby lowering his LDC tax liability from $\$ 9,000$ to $\$ 4,000$. From the US point of view, the PTK has no foreign income and thus cannot take a credit against his US tax liability. The final result is that the PTK pays tax to the United States at a rate of 25 per cent and to the LDC at a rate of 20 per cent.

In short, as long as long as the LDC tax rate is higher than the US rate, the credit results in tax being paid to the LDC at a rate equal to the excess of the effective LDC rate over the effective US rate (the 20 per cent final result in the example). As long as the PT'K's earnings are high by LDC standards, the effective LDC tax rate will probably exceed the effective US rate, and the LDC will therefore receive some tax revenue from the PTK. Should the US rate be higher than the LDC rate, however, the credit for taxes paid to the United States will exceed and thus cancel the LDC tax liability. If the rates in the example were reversed, the PTK would pay $\$ 9,000$ in US tax, and credit this foreign tax against his LDC liability of $\$ 5,000$. Under these circumstances, the LDC would receive no tax revenue from the PTK.

18. Such an approach would be similar to the US common-law rule that a person does not lose one domicile until he has acquired another.

19. Under certain conditions (e.g., marriage to an American citizen), the waiting period may be less than five years.

20. The LDC will determine the PTK's taxable income acoording to its own definition. The LDC's determination of the PTK's taxable income does not have to correspond with that of the United States.

21. Among the countries using the credit method are Canada, Greece, India, Israel, Japan, Mexico, Pakistan, the Philippines, Turkey, the United Kingdom, the United States, and West Germany. Other countries may agree to grant a credit for taxes paid to countries with which they have tax treaties. The United States, for example, requires its tax treaty partners to grant a credit to their residents for income tax paid to the United States. Elisabeth Owens, The Foreign Tax Credit (Cambridge, Mass.: Harvard Law School, International I'ax Program, 1961) p. 20, n.30.

22. For an in-depth analysis of the US foreign tax credit, see Owens, op. cit. 
If the goal of the LDC is to maximize its revenue, it should not allow a credit for foreign taxes. Moreover, no principle of international law requires a country to provide relief from the burden of double taxation. ${ }^{23}$ Indeed, if an LDC wanted to increase the economic cost of the PTK's decision to work abroad, it would adopt no relief provisions whatsoever. The lack of relief provisions may be counterproductive in a revenue sense, however, because it would encourage the PTK to evade or avoid the LDC tax.

In deciding whether or not to adopt some method of relief, the LDC must consider the attitude of the host DC, especially if the LDC will need assistance from the DC in enforcing its tax. The United States, Canada, the United Kingdom, and West Germany, all of which use the foreign tax credit as a means of relief, are not likely to help enforce an LDC tax whose burden they deem excessive. Furthermore, without some relief mechanism, the over-all tax burden on PTK earnings would be high enough in most cases to deter the PTK from emigrating. If the DCs are sensitive to the effect of the LDC tax on emigration, the LDC would have to be willing to adopt some method of relief as a precondition to requesting the DC's administrative assistance.

The credit mechanism climinates only the burden resulting from double taxation. As the effective LDC rate in the example ( 45 per cent) indicates, the PTK's income in the DC makes him appear quite affluent by LDC standards. A salary that is considered to be no more than adequate by US standards may well thrust the PTK into the LDC's upper tax brackets. An LDC income tax that would be appropriate if the PTK were living in the LDC could border on being confiscatory when measured against the cost of living in the DC. Thus the relief afforded by the credit mechanism might not be sufficient. Instead, the LDC might consider adopting a special tax for foreign income (see Part A (5) below).

4. Administrative considerations. Policing a tax on non-resident citizens creates problems even for a sophisticated tax administration such as that of the United States. Since many LDCs are inefficient tax collectors in the domestic situation, the assertion of citizenship jurisdiction over non-residents may cause severe enforcement problems. In countries plagued by low taxpayer morality and lacking experience in the taxation of foreign income, the problems will be compounded.

An LDC using a pure schedular-type system will have had no experience in taxing foreign income. Furthermore, the reason the country uses a schedular-type system and taxes only domestic income may be that its tax administration is not capable of administering a global system. 24 An LDC using a global-type system, however, will have had some experience in taxing the foreign income of its residents. Despite this experience, an LDC will find it harder to enforce a tax on the foreign income of emigrant PTKs than on that of residents.

The willingness of PTKs to comply with the tax laws of their LDCs will depend on the loyalties that they feel. PTKs may constitute a most recalcitrant group of taxpayers: not only may they fail to see the justice in a tax burden that exceeds that of their colleagues in the DC, but they may also have no intention of contributing to the costs of a government with whose policies they disagree. Secure in the belief that the LDC does not have easy access to their financial affairs in the DC, PTKs may feel confident to file a tax return containing false information. Indeed, a PTK who has cut,all ties with his LDC may see no need to file a return at all. 25 Obtaining accurate information about a PTK's taxable income is the first problem an LDC faces in administering a tax on nonresidents. Once the PTK's tax liability has been determined, the second problem lies in collecting the amount owed.

In order to obtain the information necessary to assess a recalcitrant PTK, the LDC may engage in some form of unilateral action. For example, an LDC tax administrator could go to the DC and conduct his own investigation. This approach is obviously expensive; moreover, the DC may regard the tax administrator's presence as an intrusion on its national sovereignty. For these reasons, unilateral action is rarely used unless large amounts of revenue are involved.26

A more effective and less expensive approach open to the LDC is to enlist the co-operation of the DC's tax administration. If the desired information is not already available,

23. Norr, op. cit., p. 438.

24. In some countries, the existence of a schedular system reflects the political reality that those in power have substantial amounts of foreign income.

25. The failure to receive returns from taxpayers abroad is a problem that plagues all countries. See John Surr, 'Intertax: intergovernmental co-operation in taxation', Harvard International Law Club Journal, Vol. 7 (1966) p. 203.

26. ibid., p. 182. 
it will be easier for the DC's tax administration to make the appropriate investigation than for the LDC's. Furthermore, the PTK's knowledge that the LDC can readily obtain information about his financial situation will encourage him to comply with the tax laws of the LDC by filing an accurate return in the first place.

The United States does not exchange tax information on an informal basis. Information is exchanged only under conditions specified in a tax treaty. The actual information exchanged varies from treaty to treaty. Certain readily available information, such as a list of foreign taxpayers receiving investment income from which US taxes have been withheld, may be routinely exchanged, especially if such information has already been compiled for US tax purposes. Non-routine information, for example, information on a specific taxpayer, must be specially requested by a foreign government and usually will be supplied only in certain limited circumstances. In practice, the number of individuals about whom information is exchanged is not large. 27

At the least, the LDC would want information from the United States on the income earned by any PTK who has failed to file a return. Ideally, the LDC would also want corroborative information on PTKs who have filed returns. Although compiling this information would be feasible, it would far exceed the current US practice.

Once the PTK's tax liability has been assessed, the LDC is faced with the problem of collecting the tax owed. The problem is simplified if the PTK has assets within the LDC which may be liquidated to satisfy his tax debt. Such assets would also provide the means of enforcing a penalty imposed on a PTK for failure to file a return. If the PTK has removed all his assets to the DC, 28 the LDC has four options. It may (1) ignore the tax owed until the PTK returns, if ever; (2) use non-tax measures as leverage to encourage payment of the $\operatorname{tax} ;(3)$ collect the tax through the DC's courts; or (4) ask the DC for administrative assistance.

The first option provides the PTK with an obvious disincentive to return to the LDC. Even if the PTK were to return, his accumulated tax bill might outstrip his financial resources. This option also has the disadvantage of putting the PTK in the position of being able to negotiate for a lower tax liability as a condition of his returning.

The effectiveness of the second option depends on what measures for applying pressure on the PTK are available to the LDC. For example, the PTK may have to ask the LDC to renew his passport or his medical or engineering licence, and the LDC can refuse to co-operate unless the PTK's tax liability has been satisfied.29 Certainly not every PTK will have the occasion to seek assistance from his LDC of origin, but should such an occasion arise, a PTK may not be willing to relinquish his passport or professional licence.

The third option may not be available to all DCs. The British, Canadian, 30 and American courts, for example, will not recognize a foreign tax judgement, apparently on the theory that a $\operatorname{tax}$ is an assertion of a foreign country's sovereignty which another independent country should not tolerate within its borders. A similar argument is sometimes made that taxes are closely connected with public policy and foreign relations; by ruling on the validity of foreign taxes, the judiciary might embarrass its own country or the foreign country. 31

The fourth option, engaging the assistance of the DC's tax administration, is the most effective one. Since the DC has jurisdiction both over the PTK and over his assets within the DC,

27. See Elisabeth Owens, 'United States income tax treaties: their role in relieving double taxation', Rutgers Law Review, Vol. 17 (1963) p. 450.

28. Property of the PTK may re-enter the LDC at a later date. For example, the PTK may send to relatives within the LDC cash or other property that can be seized and credited against the tax liability.

29. Compare the Venezuelan use of certificates of solvency; see Patrick Kelley and Oliver Oldman (eds.), Readings on Income Tax Administration (Mineola, NY: Foundation Press, 1973) pp. 510-15.

30. See, e.g., United States of America v. Harden, 41 DLR (2d) 721 (1963).

31. Surr, op. cit., p. 222. For criticism of this doctrine, see Lawrence Robertson, 'Extraterritorial enforcement of tax obligations', Arizona Law Review, Vol. 7 (1966) p. 219.

Although the US courts will not enforce foreign tax judgements, they will, under certain conditions, enforce non-tax judgements. The US court must be convinced (1) that the foreign court had proper jurisdiction to issue the judgement; (2) that a fair trial was conducted under a system of jurisprudence likely to secure an impartial administration of justice; (3) that the judgement was not procured by fraud; and (4) that the underlying cause of action is not contrary to the public policy of the United States. See American Law Institute, Restatement of the Law, Second: Conflict of Laws (St. Paul, Minn.: American Law Institute Publishers, 1971) § 98; see also Monrad Paulsen and Michael Sovern, "Public Policy" in the conflict of laws', Columbia Law Review, Vol. 56 (1956) p. 969. 
it is obviously in a position to bring to bear the full weight of its own collection machinery. A tax administration that is asked to provide collection assistance may either (1) refuse all collection assistance; (2) provide some collection assistance informally; or (3) agree to undertake collection assistance only in accordance with a formal commitment.

Many tax administrations have refused to engage in intergovernmental tax collection assistance of any kind. 32 A country that feels it would gain very little through such cooperation will not wish to expend its limited administrative personnel in collecting taxes on behalf of a foreign country. 33 Other tax administrations may, under certain circumstances, informally help another country collect its taxes. If a PTK does not dispute the amount of LDC tax assessed, a DC tax administration might send him a letter demanding that he pay the amount owed. This apparent joining of forces by the LDC and the DC could be enough to frighten the taxpayer into paying, even if neither the tax administration nor the courts were to take any action if the PTK ignored the letter.

The United States does not engage in collection assistance on an informal basis. Any collection assistance offered by the United States-or, for that matter, by most Western European countries-is in pursuance of a formal commitment contained in a tax treaty. 34 Most treaties have explicit provisions pledging each country's assistance to the other in the collection of taxes, but assistance is usually limited to situations in which taxpayers wrongfully seek to obtain treaty benefits. ${ }^{35}$ The case of a PTK who has failed to pay taxes to an LDC is not such a situation. Only one recent US treaty provides for assistance under more general circumstances. 36

The use of collection assistance agreements is a relatively undeveloped area. 37 Over and above taxpayer resistance to such provisions, which is undoubtedly an obstacle to their adoption, ${ }^{38}$ difficult policy questions must also be resolved. For example, under whai conditions can one country refuse to assist the other in the collection of taxes? If an LDC levies a tax only on non-residents who are PTKs, and if a similar tax would be unconstitutional if enacted by the United States, should the United States nonetheless provide collection assistance to the LDC? How can the taxpayer be protected against arbitrary conduct by the taxing country? The lack of agreement on these issues has hindered intergovernmental cooperation in the collection of taxes.
As this brief survey of existing practices indicates, some precedent does exist for international co-operation in the exchange of tax information and, to a much lesser extent, in the collection of foreign taxes. The limited amount of co-operation now being offered, however, would clearly be inadequate if more than just a few PTKs failed to comply with the LDC tax laws. Intergovernmental co-operation is thus no substitute for voluntary compliance by the PTK.

Assuming a DC was willing to offer broader assistance than usual, it might not do so without the assurance that other DCs were similarly inclined. Otherwise, any DC that was competing with other DCs for special types of PTKs (e.g., doctors) might fear that its enforcement efforts would only divert immigration to those countries not willing to offer the same assistance. Whether all the DCs could come to an agreement on the appropriate amount of assistance is doubtful.

5. Rates of an LDC tax. The amount of LDC tax liability has a strong bearing on taxpayer

32. Surr, op. cit., p. 220.

33. This feeling was also echoed in recent conversations between the authors and officials of the US Internal Revenue Service.

34. Historically, the United States has not entered into collection assistance agreements, or exchange of information agreements, independently of a tax treaty.

35. e.g., " $[E]$ ach of the Contracting States shall endeavour to collect such taxes imposed by the other Contracting State as will ensure that any exemption or reduced rate of tax granted under this Convention by that other Contracting State shall not be enjoyed by persons not entitled to such benefits.' Article 27, United States-Japan Tax Treaty.

36. 'The two Contracting States undertake to lend assistance and support to each other in the collection of the taxes to which the present Convention relates $\ldots$ in cases where the taxes are definitely due according to the laws of the State making the application.' Article 27, United States-France Tax Treaty.

37. Officials consulted in the US Internal Revenue Service could not remember any case in which the Service collected a tax on behalf of a foreign government. They stated repeatedly, 'Let them fight their own battles, we're overworked as it is'.

38. Owens, The Foreign Tax Credit, up. cil., p. 451. 
compliance, as well as on many of the other problems discussed above. Although some emigrant PTKs will not co-operate with the LDC under any circumstances, the behaviour of most will be influenced by the size of the LDC $\operatorname{tax}$ on their foreign earnings. If the burden of the LDC tax is not unreasonable, the PTK is less likely to renounce his LDC citizenship or use other means of evading or avoiding the tax. Furthermore, the DC is more likely to assist the LDC in collecting the tax if the rate is low enough not to influence the PTK's decision to emigrate or constitute a hardship while he is living in the DC. Thus considerable care must be used in designing the rate structure of an LDC tax.

The LDC can choose among a number of approaches in setting tax rates for the PTK. It can ignore the fact that the PTK is abroad and apply its regular rate schedule to the PTK's foreign earnings. In many cases, however, this approach will result in a tax burden that is heavy by DC standards, even if some relief is provided through a credit for DC taxes. 39 Alternatively, the LDC could adopt a flat rate for foreign income or if an element of progressivity were desired, a special progressive rate schedule could be designed for foreign income. A rate schedule appropriate for one DC may not be appropriate for another DC. A special schedule may therefore have to be developed for each DC.

A more satisfactory approach might be for the LDC to levy a surtax on the amount of the tax that the PTK pays to the host DC. In other words, the LDC tax would be equal to a percentage of the $\mathrm{DC}$ tax. 40 One advantage of such a surtax is that it relates the additional tax burden imposed by the LDC to the DC tax. Since the DC tax reflects what the $D C$ regards as a fair tax burden, the LDC has a convenient means of assuring that the additional burden resulting from its tax will not be unreasonable by DC standards. Demands for progressivity would be satisfied since the surtax would reflect the progressivity of the DC rate structure. Another advantage of the surtax is that the LDC need not grant a credit for DC taxes or design some other relief mechanism. 41

\section{B. US tax measures}

1. A tax on PTKs. In one version of his proposal, Bhagwati suggests that the host DCs should levy a special tax on PTKs and remit the procecds to the LDCs of origin. Whether a special US tax on PTKs would be constitutional is not clear. With respect to state legislation, the US Supreme Court has recently gone very far in striking down statutes that discriminate against aliens. 42 The Court has recognized that aliens as a class constitute a discrete and insular minority for which a heightened degree of judicial protection is appropriate. 43 Accordingly, the burden of proof placed on a state to justify discrimination is extremely heavy.

If the Court were to adopt the same standard in reviewing federal legislation, it would probably find a special tax on PTKs unconstitutional. The constitutional provision relevant to state legislation is different, however, from that relevant to federal legislation. 44 The same test may therefore not be required in determining the constitutionality of a special tax on PTKs. Furthermore, in comparison with state statutes, federal statutes contain numerous examples of discrimination against

39. See Part A (3) supra.

40. Since the DC tax applies to all of the PTK's income, an adjustment would be required if it were desired to limit the surtax to just the PTK's earned income.

41. The surtax could incorporate various refinements. For example, a floor could be provided so that a PTK who paid little DC tax as a result of taking advantage of what the LDC viewed as tax loopholes would nonetheless pay a minimum tax to the LDC. At the other extreme, a ceiling could be provided to reduce hardship.

42. Graham v. Richardson, 403 US 365 (1971); Sugarman v. Dougall, 413 US 634 (1973); In re Griffiths, 413 US 717 (1973).

43. Graham v. Richardson, 403 US 365, 372 (1971).

44. The fourteenth amendment is applicable to state legislation: ' $[\mathrm{N}]$ or shall any State deprive any person of life, liberty, or property, without due process of law; nor deny to any person within its jurisdiction the equal protection of the laws.' The fifth amendment is applicable to federal legislation: "No person shall ... be deprived of life, liberty, or property, without due process of law...' State legislation discriminating against aliens has been invalidated primarily on the basis of the equal protection clause found in the fourteenth amendment but missing from the fifth amendment. But see Bolling v. Sharpe, 347 US 497, 499 (1954) (discrimination by the federal government 'may be so unjustifiable as to be violative of due process'). 
aliens. 45 The Court might be wary of adopting an approach that would perhaps invalidate many of these federal statutes. Finally, Congress's plenary power to control and regulate immigration may limit the rights of aliens to challenge federal legislation. 46

Two important aspects of a US tax on PTKs may be of overriding importance, however. First, the primary purpose of the tax would be to protect the interests of the LDCs, whereas the discrimination in existing federal statutes is arguably in the interests of US national security. 47 Second, the tax may put the PTK at a social or economic disadvantage in comparison to a US citizen receiving the same salary; his chances of obtaining adequate housing and education, for example, would be reduced because his after-tax earnings would be lower. These differences could be enough to render the tax unconsitutional, regardless of the approach taken by the Supreme Court in reviewing federal legislation. More guidance in this area will be forthcoming because the Supreme Court is currently considering two cases in which federal statutes discriminating against aliens were successfully challenged in the lower courts. 48

Even if the legality of a US tax on PTKs were beyond question, it is extremely doubtful that Congress would enact such a tax. With no direct interests of the United States at stake, Congress is not likely to entertain a measure having such serious social and political overtones. 49 Yet without the participation of the United States, no country competing with it for PTKs could risk implementing the tax.

2. Charitable contributions. An approach available in the United States, though probably not in most other DCs, relies on the use of a tax incentive to encourage charitable contributions. Under US law, a PTK could receive a tax deduction for donations to qualifying UN agencies and organizations created under US law which use their contributions for charitable purposes within the LDCs.50 A major attraction of this approach is its lack of compulsion-the decision by the emigrant PTK to contribute funds to his LDC of origin is an entirely voluntary one.

The more financially successful the PTK is, the more he may wish to use charitable contributions to express his appreciation for educational or other opportunities afforded him by the LDC and to enable the LDC to provide sinnilar opportunities for others. The tax savings, which increase as income increases, in combination with the moral pressure on the PTK to make regular contributions, could result in large sums being made available over time. Indeed, efforts to persuade an emigrant PTK to make funds available to his LDC or to LDCs in general, might be increased the longer he was abroad, and the higher his income level. A further advantage of the tax incentive for charitable contributions is that it gives the PTK no reason to renounce his LDC citizenship.

\section{UN measures}

1. A tax on emigrant PTKs. The United Nations provides the best institutional framework for reaching agreement on the proper balance among the interests of the DCs, the LDCs, and the PTKs. It is also the most appropriate forum for resolving conflicts between the Bhagwati proposal and international law. The imprimatur of the United Nations will increase the political and moral attractiveness of a tax on PTKs; indeed, effective implementation of the Bhagwati proposal is likely to occur only under UN auspices.

One approach would be for the United Nations to levy its own tax on the earnings of emigrant PTKs. ${ }^{51}$ The host DCs would act as

45. Patrick Travers, 'The constitutional status of state and federal governmental discrimination against resident aliens', Harvard Intemational Law Journal, Vol. 16 (1975) p. 129. See, e.g., 47 USC \& 310 (1973) (denying aliens the right to hold radio station licences); 10 USC § § 3285, 5571, 8285 (1973) (denying aliens the right to hold regular commissions as officers in the US armed forces); 46 USC $\S \S 808,883$ (1973) (denying aliens the right to participate in intracoastal shipping).

46. See Takahashi v. Fish and Game Commission, 334 US 410 (1948); Fong Yue Ting v. United States, 149 US 698 (1893). See also Travers, op. cit., p. 130.

\section{Travers, op. cit., p. 129.}

48. Hampton v. Mow Sun Wong, 500 F.2d 1031 (9th Cir, 1974), cert. granted, 94 S. Ce. 3067 (1974); Weinberger y. Diaz, 361 F. Supp. 1 (S.D. Fla. 1973), prob. juris. noted, 94 S. Ct. 2381 (1974).

49. A special tax on PTKs is also difficult to administer. The problems are identical to those of a UN tax collected by a DC. See Part C (1) infra.

\section{Internal Revenue Code of 1954, § 170.}

51. The United Nations does not possess its own power of taxation. The right to tax a PTK would have to be delegated to it by the host DC or by the LDC. Neither the DC nor the LDC could delegate more power than it could exercise itself. The legality of a UN tax on PTKs will therefore depend on whether such a tax would be permitted under the laws of the DC or the LDC. 
collection agents and transmit the tax proceeds to the United Nations. A UN tax has a number of advantages. It would relieve the inequities and hardships that might result if each LDC levied its own tax on emigrant PTKs. The replacement of numerous LDC taxes with a single UN tax would contribute to administrative simplicity. By co-ordinating the collection of the tax, the United Nations would allay fears that some DCs were purposely not enforcing the tax in order to attract immigrant PTKs. The United Nations is also in the best position to develop rules for taxing PIKs who have surrendered their citizenship.

The UN tax could take the form of a surtax, for reasons similar to those discussed in Part A (5) above. At first glance, a surtax appears simple to administer since it is based on the DC tax. In many respects, however, the administration of a surtax applicable only to PTKs, rather than to all taxpayers, is equivalent to the administration of an entirely separate tax. The tax administration must (1) prepare special tax forms; (2) compile the roll of taxpayers subject to the tax; (3) design special withholding tables; (4) develop current payment programmes for the self-employed and other taxpayers not subject to withholding; (5) plan taxpayer information programmes, including the preparation of descriptive pamphlets and mass education programmes concerning filing requirements; (6) write regulations and rulings to answer ambiguities in the taxing statute; and (7) train officials to answer questions from taxpayers and to deal with disputes on appeal. Most of these problems are manageable, 52 but they must be thought through in a new context.

For example, take the problem of the establishment and maintenance of the tax roll for a surtax on PTKs. Some mechanism must be developed so that both the tax administration and employer wilhholding agents can easily separate PTKs from other taxpayers. To expect the PTKs to identify themselves without some effective enforcement machinery is unrealistic. Employers will make the appropriate inquiries only under pressure of penalties. An approach with promise appears to be for the lax administration to obtain the information from the immigration bureau.

For the immigration bureau to establish procedures for identifying newly entering PTKs would not be a major problem. 53 The information compiled by the bureau could be passed to the tax administration and entered into its computers. Computerization seems essential to the effective use of such information.
At the time of entry of the PTK, the immigration bureau will be unable to obtain two pieces of information which are extremely valuable: the current address in the $D C$ of each PTK and his taxpayer identification number. The identification number is critical in computerized operations; without it, correlating the information from the immigration bureau with the tax returns being filed would be nearly impossible. In some countries, the immigration bureau might be able to obtain the taxpayer identification number of the PTK sometime after his arrival, especially if all aliens were required to register annually.

If the tax administration is capable of identifying the PTKs, it would be able to send each of them a copy of the special tax form. The PTK could also be required to inform his employer of his status for withholding purposes. His failure to inform his employer would be detected by the computer at the time of filing and could subject the delinquent PTK to fines or other penalties. A system of directly notifying employers of the PTK status of their employees may be feasible in some countries.

2. An assessment on host DCs. Under an appropriate grant of authority, the United Nations could be given the power to levy an assessment on host DCs. The assessment would recognize the benefits accruing to the host DCs from the immigration of persons whose talents are in short supply in all countries. The proceeds would be earmarked for use in the LDCs, so that they might be compensated, at least partially, for the professional and technical skills lost through emigration and for the funds spent in educating emigrant PTKs. 54

The assessment could be a function of the number of PTKs who immigrated to the DC, the amount of their income, the amount of tax they paid to the DC, the need for their skills in

52. Somewhat analogous problems are encountered in the United States when a state decides for the first time to adopt a personal income tax.

53. Obtaining the names of PTKs already in the country, however, would be difficult, since whatever information was in the bureau's files would not be current or organized in a readily usable form. The bureau could, of course, change its procedures long before the UN tax became operational. Furthermore, the UN tax could be applied prospectively, thus excluding PTKs already in the country.

54. A host DC is obviously free to adopt a foreign aid programme based on these principles without the participation of other DCs or of the United Nations. 
the LDCs of origin, or some other combination of factors that would reflect the costs and problems of specific LDCs as well as the benefits obtained by the DCs. The administrative problems posed by a UN assessment on host DCs are modest in comparison with those encountered in levying a tax on individual PTKs. Some measure of the income of PTKs is necessary in order to compute their contribution to the host DC. Only aggregate data is needed, however, and such information can be obtained from sample surveys and crosssectional studies, which are updated periodically. The need for annual assessment and collection of tax from individual PTKs is obviated.

\section{CONCLUSIONS}

Of the three approaches examined, the least feasible appears to be a special DC tax on the earnings of emigrant PTKs. In the US context, such a tax would encounter serious political opposition and constitutional barriers.

An LDC tax on all non-resident citizens would be compatible with existing jurisdictional concepts of taxation, but the problems of enforcement are formidable. Each LDC will have to evaluate whether it can achieve the level of enforcement necessary to implement the tax.
The factors to be considered in making this evaluation are: (1) the over-all efficiency of the LDC's tax administration; (2) the LDC's prior experience with taxing foreign income; (3) the existing level of taxpayer morality; (4) the social and economic conditions that generated PTK emigration; (5) the LDC's access to the assets of emigrant PTKs; (6) possible renunciation of citizenship by PTKs in order to avoid the tax; and (7) the host DC's attitude toward assisting in the collection of foreign taxes. Most LDCs will require substantial assistance from the host DC's in administering the tax; yet little precedent exists for such widespread intergovernmental cooperation.

The United Nations appears to be the only institution that can provide a suitable framework for designing and implementing a tax on PTK earnings. The collection of a UN tax would, however, require a serious commitment on the part of the DCs. Numerous changes in existing administrative practices would be involved, and the costs of instituting the necessary machinery and procedures would be substantial. These costs would have to be estimated and compared with the revenue potential of the tax. Only then could it be determined whether the support of the DCs might be more productively channelled in some other direction in order to attain the objectives sought by the Bhagwati proposal. 